ERRATUM

Errata: http://dx.doi.org/10.1590/s1517-9702202147227768E

In the article Youth and Adult Education within the municipal sphere in Minas Gerais DOI: 10.1590/S1678-4634202147227768 published in Educação e Pesquisa, v. 47, p. 01-21, e-location e227768, 2021, please change:

Page 01 , in de footnote *:

Where it is writtten:

*Translator's note (TN): The citations, as in the Portuguese version of this text, will be presented in the footnotes as OT (Original Text).

\title{
Please, read:
}

*This article English version was financial supported by Coordenação de Aperfeiçoamento de Pessoal de Nível Superior - CAPES - Brazil.

Translator's note (TN): The citations, as in the Portuguese version of this text, will be presented in the footnotes as OT (Original Text).

Educ. Pesqui., São Paulo, v. 47, e2277682E, 2021.

DOI: http://dx.doi.org/10.1590/s1678-4634202147227768E 